\title{
Discussion on the Contemporary Value of Yunnan Anti-Japanese War Sites in the Practice of Core Value of Patriotism in Colleges
}

\author{
Jun $\mathrm{Li}$ \\ Chongqing College of Electronic Engineering \\ Chongqing, China 401331
}

\begin{abstract}
During Anti-Japanese War, there are a large number of anti-war sites and relics left in Yunnan, which not only carry the historical truth, but also are the evidence distinguishing the right and wrong in history and determining the success and failure in history, as well as the important practice and teaching base for the memory of hero and martyr and implementation of patriotism education. The national spirit with patriotism as the core is the basic content constituting the socialist core value system. In the process of implementation of education on core values of patriotism in colleges, it is possible to properly apply the Anti-Japanese War sites and cultural to teaching, and use the teaching practice activities to organize students to visit the field and let students write feedback, which will undoubtedly play a multiple effect on students' deep understanding of Anti-Japanese war, development of the spirit of Anti-Japanese War, practice of patriotism core values, hard work to achieve the great rejuvenation of Chinese nation and have a very important practical value.
\end{abstract}

Keywords-Anti-Japanese War site in Yunnan; college; practice; patriotism; core values; contemporary value

\section{INTRODUCTION}

During the Anti-Japanese War, Chinese nation suffered the baptism of blood and fire, so there are a large number of anti-war sites and anti-war cultural relics left all over the country. February 2014, Standing Committee of the National People's Congress set September 3rd as "Memorial Day of the Chinese People's Anti-Japanese War" in the form of legislation, and December 13th as "National Memorial Day of victims in Nanjing Massacre". In September 1st in the same year, the State Council announced the directory of first batch of national anti-Japanese war memorial facilities and site. On August 24th, 2015, the eve of the 70th anniversary of Chinese People's Anti-Japanese War and the World AntiFascist War, the State Council announced the directory of second batch of national anti-Japanese memorial facilities and site. In these two batches of directories, Yunnan as a rear area in wartime and the forefront of the war, owns 8 sites in total: Tengchong national War cemetery, Tengchong West Yunnan War Memorial Hall, Longling Anti-Japanese War Memorial Hall, National Southwestern Associated University site, Memorial Hall of victory in Anti-Japanese War, Battle of Mount Song site, monument of Nanyang overseas Chinese workers back to participate in antiJapanese war, Nujiang river hump route memorial hall. In addition to the above-mentioned national anti-Japanese war memorial facilities and sites, there are also a large number of anti-war memorial facilities and sites in the state-level key cultural relics protection units of Yunnan Province, as well as provincial, city (county), county (district) level cultural relics protection units. According to the statistics of Provincial Cultural Relics Bureau, Anti-Japanese War cultural relics in Yunnan Province amount to over 140. In addition, since the Yunnan army went out of the province to fight for the war and fight outside China as expeditionary forces, there are also many Anti-Japanese War sites and memorial facilities belonging to Yunnan in other provinces and other countries. For example, the Shandong Taierzhuang war Memorial Hall, Jiangsu Yu Wangshan Anti-Japanese War memorial park, etc. are the national anti-Japanese war memorial facilities and sites announced by State Council in 2014 and 2015. The above anti-Japanese war memorial facilities, sites and anti-war cultural relics are the precious historical witness of the great Anti-Japanese War, which not only need cherishment and protection, but also should be given full play to its function of patriotism education base. Although time passes, history cannot be forgotten. Chinese people paid a great sacrifice in Anti-Japanese War. However, after the war, Japanese militarism was not subject to deserved blame, and even brazenly resurrected. Currently, the right-wing forces in Japan continue develops constantly in an attempt to challenge the international order formed after World War II. Therefore, it has a very important contemporary value for realization of the great rejuvenation of the Chinese nation to properly apply the anti-Japanese war memorial facilities and sites to education on core values of patriotism in colleges so that students can remember the history, cherish the vigorous, carry forward the spirit of AntiJapanese War, and carry out education on core values of patriotism.

II. ANTI-JAPANESE WAR Sites IN YUNNAN ARE THE Classic TEXTBOOK OF EDUCATION ON CORE VALUES OF PATRIOTISM

President Xi Jinping clearly point out that "it is necessary to strengthen the protection and development of Anti- 
Japanese War sites and give play to various anti-Japanese war memorial facilities to provide positions for carrying out anti-Japanese war research, presenting the results of the war and implementing patriotism education." [1]The national spirit with patriotism as the core is the basic content of the socialist core value system. Patriotism is the fine tradition of Chinese nation. Since ancient times, all ethnic groups have a lot of people who made outstanding contributions to the country and the nation. Their heroic performance is memorized by history, which is also a model for college students to practice core value of patriotism. During AntiJapanese War in Yunnan, Chinese Expeditionary Force cooperative combat with Allied forces in Burma, northeastern India and the western region of China, restraining the aggressive arrogance of Japanese invaders in Southeast Asia, opening the Burma Road and Ledo Road, ensuring the only unblocked international road of China's long-term Anti-Japanese War and recovering the vast territories occupied by Japanese, which made an important contribution for the victory of Anti-Japanese War and world anti-fascist war. In order to commemorate martyrs, highlight the anti-Japanese performance of the Expeditionary Forces, the original senior generals of expeditionary army, Du Yuming, Sun Liren, etc. established monument for the fallen soldiers of Anti-Japanese War in the end of the war and after the victory of war in Kunming, Guangzhou and other places successively. In 1944, the defensive commander of Kunming and the commander of Fifth Army Du Yuming established a monument for the Burmese Campaign in Yuantong Park of Kunming. Because the original commander of the twohundredth division of fifth expedition army, Dai Anlan was brave and skillful in battle and achieved outstanding exploits in Burma war, and finally martyred, this monument was named "Anlan monument." Du Yuming buried a square stone with "foundation commemorate" written by him in the soil, and made a speech to encourage subordinates to inherit the behest of Dai Anlan and other expedition martyrs, expel the Japanese, and recover the territory. Chiang Kai-shek, He Yingqin, Long Yun, Xu Tingyao and Wei Lihuang also wrote an inscription. This monument was renamed "monument for Chinese fallen soldiers in Burma Campaign." Tengchong national War cemetery was built in the winter of 1944 , and opened in July of the next year. In the summer of 1944, in order to recover the lost land, complete the strategic plan of opening the Burma Road, and support the army in India to fight in Northern Burma, the twentieth expeditionary army of Chinese Expeditionary Army send six divisions to launch a counterattack to the Japanese army that occupied Tengchong for 2 years. After more than 80 battles of various sizes, we recovered Tengchong on September 14, and the enemy chieftain kurashige yasumi colonel and his subordinates of more than 6,000 people were all annihilated. Our Expeditionary Force also lost Major General Li Yi, Qin Zibin and other 8,000 soldiers, more than 1,000 local armed officers and 19 soldiers of allied forces (the United States) were killed. [2]As couplet Mr. Chen Zhisui wrote in "Tengchong national war cemetery": "fighting with Japanese regardless of body makes numerous body badly mutilated, so hundred generations memorize the martyrs; this teaches the nation to be diligent and calm the heart to memorize the lesson of aggression for thousands years." The cemetery covers an area of 88 acres, with the building area of 9826.8 square meters, which is divided into museum, martyrs temple, martyrs tomb, and monument. The wall is embedded in more than 20 title monuments of the soldiers with 9618 people in total. Martyrs tombs are built around the tower, amounting to 3646. [3]In order to commemorate the overseas Chinese mechanic of Nanyang returning to China to participate in anti-Japanese war, Yunnan has also established monuments in Xishan Park of Kunming and Wanding National Forest Park of Dehong successively, so that later generations will memorize them forever. After the outbreak of the war, the compatriots united against Japan, and overseas compatriots also share a bitter hatred of the enemy. In 1939, responding to the call of Chen Jiageng, Chairman of the general assembly of Nanyang Overseas Chinese Relief for the Refugee in China, overseas Chinese descendant returned home to participate in the fight against the Japanese, and set off a vigorous anti-Japanese national salvation movement. 3193 hot-blooded Nanyang overseas Chinese machinists traveled accross the ocean to the motherland, composed "Nanyang overseas Chinese machinist team", and engaged in the sacred anti-Japanese national salvation service work, 1,800 of whom died successively. In addition, there is cenotaph for fallen sodiers of 198 divisions conquering Tengchong in Yunnan, China Expeditionary Cemetery site in Dali March Street, cemetery for fallen soldiers and sick soldiers in the 261 regiment of Chinese Expeditionary Force killed. The epitaph of Chinese Air Force Cemetery said: "Dian Sea is surging and Qing hill is luxuriant. The spirits of martyrs in Anti-Japanese War are sleeping here. Our national integrity is as great as a mountain. Remember the past and it will guide your future". The cemeteries are outstanding teaching materials for memory of the martyrs and the patriotism education as well as precious cultural heritage that carries forward the national spirit, to strengthen the national spirit and enhance patriotism education.

And the War Memorial Hall is the key construction project of cultural facilities in Yunnan Province. For example, the Memorial Hall of Western Yunnan AntiJapanese War, which covers an area of 22 acres, with a total construction area of 9492 square meters, is not only the largest memorial hall of Anti-Japanese War in Yunnan, but also the only one commemorative venues that was constructed with the financial support of Central Government in Chinese mainland to commemorate the Chinese Expeditionary Force and anti-Japanese heroes in Burma campaign. The memorial hall can be divided into 7 parts, namely the rear of the anti-Japanese war, the front line of the resist of enemy, Nujiang confrontation, Jedi counterattack, the expulsion of enemy out of the country, veterans never die and the pray for peace, with a total of more than 88,000 pieces of cultural relics collected at home and abroad. The name list wall of the Chinese Expeditionary Army was constructed next to the main exhibition hall, with a total length of 133 meters, which is engraved with 103141 names of the expedition army, allied troops, local antiJapanese guerrillas and local war casualties who had participated in the western Yunnan war as well as the names 
of the troops and unit personnel involved in the war. [4]The Longling Anti-Japanese War Memorial Hall is located in Longshan town, Longling County, Baoshan City, which is built to commemorate the anti-Japanese war in western Yunnan. The Memorial Hall covers an area of 7.8 acres. It is mainly composed of the commemorative altar, the spring of expedition, the Japanese bunker, large relief landscape, memory pool, flag tower, ever-ringing bell and the memorial hall of anti-Japanese war. The exhibition is divided into eight parts: "all people of one mind to fight a bloody battle", "Japanese Army invading, no backwards step", "unwilling to be enslaved, live up to struggle", "mobilize the army to organize counterattack". [5]In addition, the Nujiang Hump Air Route Memorial Hall, and the Memorial Hall of General Zhou Baozhong, general director of the 2th Road Army are also important cultural heritages of Yunnan. These memorial halls not only can reproduce the hardships and tragedy of the Anti-Japanese War and the patriotism of desperate sacrifice of the Chinese soldiers, but also is an important practical teaching base for patriotism education. If these gravestones, memorial halls and other anti-Japanese war sites and relics can be made into videos with commentary for the college students, it will undoubtedly play a multiple effect on making the students have an deep understanding of the history of the war, not forget the humiliation, strive to be strong and carry forward the spirit of the war.

\section{THE ANTI-JAPANESE WAR SITES IN YUNNAN ARE THE HORN TO EVOKE THE PATRIOTIC FEELINGS OF EVERY COMMON PERSON}

As the common saying goes, "Every man alive has a duty to his country." Our contemporary college students, as a part of the 1.3 billion common people, should not only inherit the patriotic tradition and carry forward the patriotism, but also be a loyal patriot who must consciously safeguard national interests, promote national unity, safeguard the reunification of the motherland and enhance the concept of national defense and National security awareness. During the teaching of the core values of patriotism, it is possible to introduce all kinds of information about the great contributions that the Yunnan people have made to the country during the Anti-Japanese War so that students can truly realize the love between people and the country. The Yunnan people are unknown people, but they are also an amazing group who had made great contributions to the country. The soldiers and people were the basis of the victory of the war, during the eight years of war, Yunnan had levied two "one million" common people to build roads, and support the front line, who had changed the fate of China. One million common people built China's last "lifeline" with their flesh and blood: the infrastructure construction and demolition of $880 \mathrm{~km}$ of Yunnan-Burma railway, $959.4 \mathrm{~km}$ of Burma Road, 52 military airports. In October 1937, the National Government ordered the mobilization of 200,000 Yunnan migrant workers to build the Burma Road. Due to the serious lack of construction machinery, people can only use their hands to build one of the most rugged roads in the world. The vast majority of the labors of all ethnic groups are the elderly, women and children, because most young adults have been to the central plains to participate in the war.
Millions of peasants wielded their own farm tools, facing the malaria, disease, death, and fought against millions of mountains. The women carrying their babies on back also came to construct the road with their back bent, and even pregnant women spared no effort to work. According to statistics, the Burma Road is made of earthwork of 19983960 cubic meters and stone of 1875497 cubic meters. [6]These earth and stone are all picked away by the workers with their shoulders. There is no roller, so the big stone roll served as the only tool to compact the roadbed. The gravel required by Burma Road is hammered by women and children with shovels, hoe, dustpan and other original tools. On August 31, 1938, through 20 million people's hard work, the Burma Road was opened to traffic. From start to open, construction only took 9 months, which shocked the world. The completion of the Burma Road is a miracle, which is the road of hope built by the flesh and blood of 200,000 women, children and labor of all ethnic groups in Yunnan as well as the road to victory of the war against Japanese. According to incomplete statistics, after the victory of the war, there are two or three thousand people permanently sacrificing their life to the road. In May 1939, there was "monument of the dead building the Burma Road of Tengchong County" in the big Yakou of Pine Mountain where the inscriptions recorded: "overcoming all obstacles to dig the stones. People from various districts and counties who participated in it amounted to fifty thousand, the grain provided by local government was up to two million yuan, and people died of malaria are as many as two thousand. However, after that year, repair and reinforcement projects of the highway need more than 10,000 people. This time, according to the policy of the nationwide Anti-Japanese War, every man should do their part. We should dedicate our full efforts for the country, and work in the rear area, which is the same as the soldiers bleeding at the forefront. Not having done one's best is irresponsible. We cannot bear name of the dead are forgotten, so we build this monument to record." The back of the monument is also engraved with the name of the dead. On April 26, 1943, 54 bombers and numerous zero fighters of Japan bombed and strafed on the more than 20,000 workers who are constructing Yunnan Railway Station at a low altitude, killing 406 people on the spot, and making 200 people seriously injure. The next day, the air raid came again, resulting in the death of more than 200 people. Some of the workers were dead with the ropes around their bodies, which are "like fish strung by a rope, and dead in a string." A mountainous pile of corpses were carried by trucks for three days, and finally buried in the "mass grave" in Mahuanging. According to incomplete statistics, during the eight years of Anti-Japanese War, among the Yunnan people who participated in the repair of the Burma Railway, Burma Road and 52 military airports and ancillary facilities, the dead summed up to 100,000 . [7]

Another one million people attended the war in western Yunnan, expeditionary forces and South Yunnan defensive war. In May 1944, the 160,000 Expeditionary Force was in front of the Millions of civilians. Where the troops went, ammunition, food, vegetables, pork, beef, horse grass and even coffin were sent there. At the end of 1945, County magistrate of Baoshan, Meng Liren recorded the statistics of 
the county's large-scale supporting the front in a report: civilian workers are 4160324 person-time; mules and horses are 1193655 times; cattle are 323297 times; dead workers ( killed by the enemy at the front or died of fatigue in the way and died of miasma) are 3854; dead mules and horses are 14904; dead cattle are 11100; firewood supply is $11824117.5 \mathrm{jin}$; coffin supply are 13350; telegraph and telephone poles are 5494; ration rice is 200,000 bags, add up to 15.4 million $\mathrm{kg}$; horse feed is $4461904 \mathrm{~kg}$; horse grass is $9530787 \mathrm{~kg}$; pork and beef is $232299.5 \mathrm{~kg}$; plate are 23812 jin; plating poles needs 18900 people; furniture are 68184 pieces ... ..." [8]These figures are "enormous figures" even in today, but they are actually from a county in ethnic minority poverty-stricken area on the border. Hupo transport of grain is the most tragic expedition of civilians in Tengchong in the counterattack of western Yunnan. At the critical juncture when soldiers at the front exhausted supplies and ammunition,3 million civilians of Tengchong were ordered to transport 60 million pounds of military grain from Hupa at the foot of the mountain, to the east coast of the $\mathrm{Nu}$ River crossing Gaoligong Mountain of 3,000 meters above sea level. Just over 40 days, more than 3800 people died, frozen to death, starved to death, died of illness, fell to death on the road of transport of food. Subsequently, expeditionary forces besieged Tengchong, and nearly 100,000 people participated in digging fortifications and carrying ammunition supplies, so many people died in the fire. [9]A lot of people had been moved by the Yunnan civilians who also touched Brigadier General Frank Dore, the chief of staff of US Military Assistance Advisory Group of Chinese Expeditionary Force. , After the victory of the antiJapanese war, he wrote in his memoir named "Battlefield in the Cloud": "it seems that the rain in western Yunnan will never stop. It is the first time I saw the awful and great Nujiang River valley. Compared with the Grand Canyon Colorado, it is so much more precipitous. A troop of more than one hundred thousand people, ten thousand horses and donkeys, more than 20,000 heavers scattered in the precipitous and winding mountain roads, and moved towards the howling rapids of the river. The tinkles of the copper bells on the body of mules are echoing in the valley with the depth of seven to eight thousand yards. When they are reaching the unpredictably high and dangerous areas, thousands of mules, horses, and coolies slipped down from the frozen defile, fell and died in the deep ditch of thousand feet. The battle was carried out in a world of ice and snow with a high elevation of 11,000 feet which is covered by thick clouds. It is the land battle of the highest elevation during the second world war, which is known as the battlefield on the clouds." [10]"This two million common people" offered the battle with the food, grass, labor force and own lives, and they struggled to ensure the logistical support of the battlefield of Dianxi Anti-Japanese War with their most primitive lives which had decided the define of China, and all what they had done explained the old saying that " Every man has a share of responsibility for the fate of his country ". It is exactly as General Song Xilian said, people in Yunnan province "on the one hand endured the pain, on the other hand they supported the counterattack with great enthusiasm, which had played a decisive role on the victory of this war." [11]

Due to the patriotism spirit of the Chinese nation of "sacrificing one's wealth to save the state, and running toward the flame", the anti-Japanese war made the final victory. It is also the first war of complete victory of China against foreign aggression since modern times. Xi Jinping pointed out that: "This war of great victory had completely smashed the attempt of Japanese militarism to enslave China and had washed off the national shame of repeated defeats in the wars of China against foreign aggression since modern times, this great victory, had re-established the great power status of China in the world, and also made the Chinese people win the respect of the peace-loving people all over the world. This great victory, opened up a bright future for the great rejuvenation of the Chinese nation, and started a new journey for the rebirth of ancient China. [12]"Patriotism is the spiritual pillar for the development of Chinese nation is the spiritual power to realize the great rejuvenation of Chinese nation, and it is also the source of strength for college students to realize the value of individual life.

The education of the core values of patriotism in colleges and universities can be absolutely taught by practice activities and organizing the students to visit the memorial facilities and ruins of the anti-Japanese war, so that the students can feel the temperature of the war and worship the spirit of patriotism in front of the thousands of silent antiJapanese war sites in the "sound of wind, rain, and reading", look up at the great achievements in anti-Japanese wars of the ancestors in the eyes of "home, national and global affairs", and by letting the students to write a feedback so that they can truly realize the anti-Japanese war spirit of Dianxi: "galloping at full speed to sacrifice own life for the sacred territory and the border area of southwest. Suffering from wind and rain to knock down the stubborn enemy; suffering from hunger and cold to make great achievements. Among twenty thousand people, few of them survived, making numerous relatives of them be abandoned. A victory of a war makes millions of bones withered, while the generals are in an agony of pain and sorrow. To die a hero's death with satisfaction and smile, but for the unfinished deeds, we shall make more efforts. The winning of the counterattack war is so precious, and ranks the best in the glory of Chinese history. Survivors remain alive, while the deceased rest in peace. Giving own live in the wars for the country, the spirit of heroes will go down in history forever. In the annals of history, it is full of heroic spectrum, while in the universe, it is shining forever as the sun and the stars". [13]

\section{ANTI-JAPANESE WAR Sites IN YUNNAN ARE THE SPIRITUAL MOTIVE OF PRACTICING THE CORE VALUES OF PATRIOTISM}

Mao Zedong profoundly pointed out in "On the Protracted War" that the Sino-Japanese war is a protracted war, and the final victory of the war certainly belongs to China, but the sacrifice will be big, through a very painful period. During the 8 years of Anti-Japanese War, China paid 
a heavy price. A total of 35 million people and casualties died, property losses are more than 600 billion US dollars (based on the US dollars in 1937, the same below), the war consumed more than 400 billion US dollars, and indirect economic losses are 300 billion US dollars. [14]And the Anti-Japanese War sites in Yunnan can reproduce the cruelty and horror of the war more clearly. For example, among the Anti-Japanese War sites in West Yunnan, battle site in Huipo, Longyang, round-up war site in the North public house, round-up war site in the South public house, Pine mountain battle site, and counterattack Lujiang wood trees fighting sites are the battlefield sites with the largest sacrifice and the most difficult fights in western Yunnan counterattack war. The war began on May 11, 1944, and ended on January 27, 1945, which lasted more than eight months. After the fierce competition, we finally won the victory of the counterattack. According to the report of "Statistics of West Yunnan Battle" in December 1945 made by National Government: in Western Yunnan anti-Japanese counterattack campaign, dead and injured soldiers in China are as many as 50474. [15] May flowers bloom all over the wilderness, while flowers cover the blood of the patriots. In order to save the nation in danger, they have been tenacious to fight against the enemy." [16]If the expeditionary armies that participate in Burma campaign for the first time are added, the casualties are 56480 people, and the second time, the Chinese casualties are more than 1.8 million person. In just two years, the Chinese casualties in the Burma battlefield are as high as 120000 people. [17] "Shame for a thousand years will finally be avenged, while resurgence of industry needs outstanding people." [18] When commander of the Chinese Expeditionary Army Wei Lihuang reviews the Burma campaign, he points out in particular: "especially in the Tonggu battle, the heroic fights of two hundred divisions actually gave enemy with high aggressive arrogance unexpected bitterly hit so that the friendly forces of British and Indian troops got the opportunity to take a breath. Others such as the Battle of Pyinmana, Tang Ji's attack and rescue of British army, etc., are records worthy of domestic commendation. Finally they turned to the northern part of Burma, when commander Dai and Anlan bravely die for our motherland, which had gone through hardships, so many soldiers died in foreign lands for the glory of the nation. We know that these loyal soldiers who sacrificed for the country are always worthy of admiration of future generations. We establish monument to commemorate them today to inherit their behest, so we need to work hard, wipe out the Japanese invaders, and recover the lost territory to comfort their spirit." [19]70 years later, although the smoke of war has dispersed for a long time, but there are a large number of anti-Japanese sites group of defensive building left in Shidian County, which are the important historical witness of the confrontation between expeditionary forces and Japanese army. In addition, Haipo mountain battlefield site in Shidian County, the old ferry battle site, the Anti-Japanese War site in southern Yunnan, minority anti-Japanese war site, the Chinese Expeditionary Force and the Burma Army fighting sites, and even the tragic history of China's war of resistance, these sites are not only carried by the Chinese people against foreign aggression, for national independence and liberation of major historical events, but also evidence revealing the historical truth, distinguishing the right and wrong in history and determining the success and failure in history. Besides, it is also the precious cultural heritages of Anti-Japanese that carry forward the national spirit and make the patriotic education, which has a very important contemporary value.

\section{CONCLUSION}

At present, the competition of comprehensive national strength between countries is increasingly fierce, so the important guarantee for the Chinese nation to be invincible is to uphold the banner of patriotism. College students should vigorously carry forward the spirit of Anti-Japanese War in Yunnan, encourage themselves by the heroic behaviors of heroes in Anti-Japanese War, consciously assume the historical mission of the realization of the Chinese dream, strive to determine to serve the country, add the talents for construction of country and practice patriotism, and grow to be useful talents for the nation and society.

\section{REFERENCES}

[1] Xi Jinping: "Speech In commemoration of the 70th anniversary of the Chinese people's anti-Japanese war and the victory of the world antifascist war", September 3, 2015, Chinese communist party history network, the CPC Central Committee History Research Office.

[2] Display information of Memorial cemetery in Tengchong, Yunnan.

[3] Display information of western Yunnan Memorial Hall for AntiJapanese War in Tengchong, Yunnan

[4] Display information of Anti-Japanese War Memorial Hall in Longling, Yunnan.

[5] Cultural and Historical Records Committee of Yunnan Provincial Committee of Chinese People's Political Consultative Conference, Selections of cultural and historical documents in Yunnan, No. 8, 47, pp. 47,52,75,205,301, the , 1995.2 (1)

[6] Liu Yun: Silent Feelings--Album for Anti-Japanese War Sites in Yunnan, Yunnan People's Publishing House, 2015, pp.4,5,79

[7] Wei Lihuang, Yao Zifan, Eulogy for triumph and mourning for national martyrs, Ta Kung Pao, 1944.5 (3)

[8] History Research Department of Academy of Military Sciences, History of Anti-Japanese War in China (volume two), Chinese People's Liberation Army Publishing House, 1994, pp. 625

[9] Guang Moran, lyrics of Flowers in May, 1943

[10] Lyrics of school song of Southwest Associated University. 